\section{Barex \\ SciencePark Research, Organization \& Counseling \\ Global Journal of Foreign Language Teaching}

Volume 7, Issue 2, (2017) 76-85

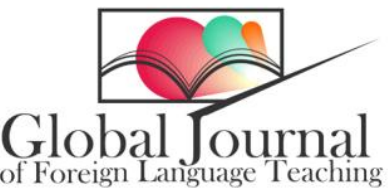

www.giflt.eu

\title{
Teaching in multilingual education: Syllabus design based on the principles of multilingualism
}

Arijeta Selimi*, Faculty of Languages, Cultures and Communication, South East European University, Tetovo 1200, Macedonia.

\section{Suggested Citation:}

Selimi, A. (2017). Teaching in multilingual education: Syllabus design based on the principles of multilingualism. Global Journal of Foreign Language Teaching. 7(2), 76-85.

Received from November 05, 2016; revised January 29, 2017; accepted April 10, 2017.

Selection and peer review under responsibility of Assoc. Prof. Dr. Ali Rahimi, Bangkok University, Thailand.

2017 SciencePark Research, Organization \& Counseling. All rights reserved.

\begin{abstract}
This study is dedicated to the field of didactics in multilingualism, and presents the theories of didactics and didactics in multilingualism by explaining their differences. In addition, this study presents an overview of the definitions and models of didactics in multilingualism; and it suggests a model which can be implemented in a classroom with multilingual students, who lea $m$ German as a fourth language (L4). Finally, this study presents a lesson plan for students who have al ready lea med three langua ges with English as their third language (L3) and a re in the process of acquiring German as theirfourth language (L4).
\end{abstract}

Keywords: Didactics in mul tilingualism, models of mul tilingualism, lesson planning.

* ADDRESS FOR CORRESPONDENCE: Arijeta, Selimi, Fa culty of Languages, Cul tures and Communica tion, South East Eu ropean University, Tetovo 1200, Ma cedonia. E-mail address: a rijetaselimi @yahoo.com / Tel.: +38944356 000 


\section{Introduction}

The sociolinguistic situation and the advancement of the policy of foreign languages in countries demands from teachers of foreign languages to look for clear answers and concepts or guidelines for their didactic-methodical implementation. This is confirmed by many studies such as Meibner, Reinfried, Hufeisen, Neuner and others. They state that international books of German as a foreign language lacks the account of the influence of previously learned languages. This study addresses the questions on how and which didactic-methodical views could facilitate the learning of German as a foreign language, with regard to specific constellation in Macedonia, which brought the idea to study the development of language teaching methods and introduce the didactic of multilingualism. Furthermore, it discusses whether a textbook for German as a foreign language can enhance language transfer through appropriate tasks and exercises, i.e., how a proper language typology exercise looks like in a multilingual context considering the influence of the native language, in conclusion, the results of students.

\subsection{Key concept}

In foreign language teaching, the historical change of the methods of the professional area of the German language as a foreign language has a key role. The most important methodological paradigms that have predominated during the history of the didactics of foreign languages was briefly presented in the course of the effort, in order to achieve the linkage with the didactics of multilingualism and the need learning. For a description of the historical development of the methods in the didactics of foreign languages, the historical review of Neuner (2003, p. 225 234), Neuner/Hunfeld (1993, 19 122) and Reinfried (1998, 23 24), will be used.

\subsection{Presentation of the theories of didactics and didactics in Multilingualism - differences of the definitions and models of didactics in multilingualism}

The first, the oldest method of learning a foreign language, the Grammar translational method, was based on grammatical rules and the principles of language construction. Text translation from the learned language to the native language and vice versa was the proof for the knowledge of the foreign language that was the characteristic of the grammar translational method (Neuner, 2003, p. 227).

Furthermore, there are other methods: The Reformist method or the Direct Method. The content orientation of the direct method was to enable the students to think in the foreign language (Reinfried, 1998, p. 24). Thus, the language of instruction is extremely limited to the targeted foreign language (Schmidt, 1890, p. 73, according to Kom, 1896, p. 84; Reinfried, 1998, p. 23; Zergiebel, 1893, p. 11,13). The learning of a foreign language is practised through hearing and repetition of the spoken language. Whilst the Audio called as army method was developed by building on the direct method following the pragmatic and pedagogical goals (Neuner, 2003, p. 228f; Neuner/Hunfeld, 1993, p. 45, 58). Linguistic laboratories are the characteristic for ALM. The Audio visual method (AVM) The study of the foreign language via AVM follows the teaching principle of using optical teaching aids. Communicative didactics was focused on a pragmatic and pedagogical perspective (Neuner/Hunfeld, 1993, p. 84). She took and perfected the pragmatic impulses of ALM/AVM

Neuner/Hunfeld, 1993, p. 88) and develops a linguistic-functional concept in order to implement the everyday communicative situations in teaching (at the same place), whilst the

(Neuner, 2003, p. 228f; Neuner/Hunfeld, 1993, p. 45, 58). 
The neo-

new form of expression of the communicative method.

considered as a

A very compact resume for the actual tendencies in the didactics of the foreign languages is given by Reinfried (2001, p. 1 20). Reinfried (2001, p. 10) with the help of a picture presents the principles of the neo-communicative teaching of a foreign language. Here it can be seen that didactics of multilingualism coincide with the principle of learning with interdisciplinary teaching.

Table 1. Display of the principle of neo-communicative teaching in foreign language learning (Reinfried, 2001, p. 10)

\begin{tabular}{lll}
\hline Teacher centred & $\begin{array}{l}\text { Creative work. Learning through } \\
\text { teaching. Teaching through } \\
\text { project work. }\end{array}$ & \\
Interdisciplinary learning & $\begin{array}{l}\text { Multilingual didactics Bilingual } \\
\text { Interdisciplinary teaching } \\
\text { content- based learning }\end{array}$ & $\begin{array}{l}\text { Interlanguage coordination } \\
\text { of the language input. } \\
\text { Interlanguage learning } \\
\text { strategies. Communicative } \\
\text { Learning experiences }\end{array}$ \\
& $\begin{array}{l}\text { Authentic and complex learning } \\
\text { situations Unexpected learning } \\
\text { Personalised learning students }\end{array}$ & $\begin{array}{l}\text { Learning with all senses. } \\
\text { awareness }\end{array}$ \\
& autonomy & $\begin{array}{l}\text { Student consciousness } \\
\text { (strategies and techniques } \\
\text { of learning). Language } \\
\end{array}$ \\
& & $\begin{array}{l}\text { consciousness. Intercultural } \\
\text { consciousness. }\end{array}$ \\
\hline
\end{tabular}

Starting from the historical development of theories of didactics and following the nee ds of the development of the society, the rapid growth of communication between people and nations, the growing need to learn languages of their fellow citizens as well as in the international level, and the need for co-ordination of all the studied languages appears in the head of the multilingual man, as well in education.

This paper follows an attempt to achieve a summary of the objectives and strategies of multilingual didactics of the foremost multilingual scholars (Meibner, Reinfried, Hufeisen) that follows as an addition in Table 1. 
Table 2. Review of methods up to the communicative approach on the website and the added PD

\begin{tabular}{|c|c|c|c|c|c|}
\hline & $\begin{array}{l}\text { Grammarian- } \\
\text { translational } \\
\text { method }\end{array}$ & $\begin{array}{l}\text { Direct } \\
\text { method }\end{array}$ & $\begin{array}{l}\text { Audio-lingual } \\
\text { method / Audio } \\
\text { visual method }\end{array}$ & $\begin{array}{l}\text { Communicational } \\
\text { didactics }\end{array}$ & $\begin{array}{l}\text { Multilingual } \\
\text { didactics }\end{array}$ \\
\hline $\begin{array}{l}\text { Period of } \\
\text { creation } \\
\text { /conditions }\end{array}$ & $\begin{array}{l}\text { 19centuries } \\
\text { from the old } \\
\text { languages (Latin } \\
\text { - Greek) }\end{array}$ & $\begin{array}{l}\text { Reformist } \\
\text { movement of } \\
\text { the } 20 \mathrm{~s}\end{array}$ & The 60s & $\begin{array}{l}\text { The beginning of } \\
\text { the } 70 \mathrm{~s} \text {, the } 80 \mathrm{~s} \\
\text { in continuity }\end{array}$ & $\begin{array}{l}\text { The end of the } \\
80 \text { s, the beginning } \\
\text { of the } 90 \text { s, still in } \\
\text { development } \\
\text { (Hufeisen, } 2003 \text {, } \\
\text { p. 11) }\end{array}$ \\
\hline $\begin{array}{l}\text { Linguistic } \\
\text { conditions }\end{array}$ & $\begin{array}{l}\text { Latin grammar, } \\
\text { language } \\
\text { understood as a } \\
\text { building: blocks } \\
\text { + logical rules }\end{array}$ & $\begin{array}{l}\text { Behaviorism } \\
\text { method of } \\
\text { association }\end{array}$ & $\begin{array}{l}\text { Behaviorism } \\
\text { structuralism } \\
\text { Linguistics }\end{array}$ & $\begin{array}{l}\text { Structuralism } \\
\text { Contextualism } \\
\text { Pragmalinguistics }\end{array}$ & $\begin{array}{l}\text { Neurolinguistics, } \\
\text { psycholinguistics, } \\
\text { Contextualism, } \\
\text { pragmalinguistics, } \\
\text { hypothesis } \\
\text { grammar }\end{array}$ \\
\hline $\begin{array}{l}\text { Methodological } \\
\text { didactic } \\
\text { principles }\end{array}$ & $\begin{array}{l}\text { Goal: use the } \\
\text { constructive } \\
\text { rules of the } \\
\text { language, } \\
\text { orientation in } \\
\text { the written } \\
\text { language. } \\
\text { language of } \\
\text { instruction: NL }\end{array}$ & $\begin{array}{l}\text { Goal: } \\
\text { implementing } \\
\text { language as a } \\
\text { mean for } \\
\text { comm. } \\
\text { Instruction } \\
\text { language: the } \\
\text { foreign } \\
\text { language }\end{array}$ & $\begin{array}{l}\text { Goal: learning } \\
\text { the FL in typical } \\
\text { situations } \\
\text { Visually as aid } \\
\text { to explain and } \\
\text { support the } \\
\text { memorisation } \\
\text { Language of } \\
\text { instruction: The } \\
\text { NL }\end{array}$ & $\begin{array}{l}\text { Goal: comm. } \\
\text { skills, mediation } \\
\text { of the student } \\
\text { oriented learning } \\
\text { strategies, LI: FL } \\
\text { but the NL is also } \\
\text { allowe }\end{array}$ & $\begin{array}{l}\text { Goal: early, } \\
\text { intensive and } \\
\text { interdisciplinary } \\
\text { language learning } \\
\text { Meibner (1998, p. } \\
\text { 18) }\end{array}$ \\
\hline $\begin{array}{l}\text { Theory of } \\
\text { learning }\end{array}$ & $\begin{array}{l}\text { Cognitive } \\
\text { synthetic } \\
\text { deductive }\end{array}$ & $\begin{array}{l}\text { Imitative } \\
\text { analytical } \\
\text { inductive, } \\
\text { discovery } \\
\text { learning }\end{array}$ & $\begin{array}{l}\text { Imitative } \\
\text { (closer to } \\
\text { natural } \\
\text { adoption of the } \\
\text { language - } \\
\text { imitative) }\end{array}$ & $\begin{array}{l}\text { Analytical } \\
\text { inductive } \\
\text { discovery } \\
\text { learning }\end{array}$ & $\begin{array}{l}\text { PJD participates } \\
\text { clearly and } \\
\text { actively in the } \\
\text { foreign language } \\
\text { learning } \\
\text { (Hufeisen/Neuner, } \\
2003, \text { p. 19). } \\
\text { Comparative and } \\
\text { discoverylearning }\end{array}$ \\
\hline Skills & $\begin{array}{l}\text { Reading/writing } \\
\text { /translation as } \\
\text { usage of } \\
\text { grammatical } \\
\text { knowledge }\end{array}$ & $\begin{array}{l}\text { Listening } \\
\text { speaking } \\
\text { before } \\
\text { reading- } \\
\text { writing, } \\
\text { learning the } \\
\text { pronunciation }\end{array}$ & $\begin{array}{l}\text { Priority for the } \\
\text { oral: listening } \\
\text { speaking }\end{array}$ & $\begin{array}{l}\text { Integration of } \\
\text { skills, relevance } \\
\text { of the individual } \\
\text { learning } \\
\text { objectives }\end{array}$ & $\begin{array}{l}\text { Integration of } \\
\text { skills, restoring } \\
\text { the already } \\
\text { developed type of } \\
\text { learning and } \\
\text { knowledge of the } \\
\text { language }\end{array}$ \\
\hline $\begin{array}{l}\text { Texts in the } \\
\text { school books }\end{array}$ & $\begin{array}{l}\text { Non authentic, } \\
\text { produced texts } \\
\text { for the } \\
\text { school book 2) } \\
\text { classical, } \\
\text { literary }\end{array}$ & $\begin{array}{l}\text { Spoken } \\
\text { language, } \\
\text { everyday } \\
\text { situations, } \\
\text { songs, } \\
\text { poems, } \\
\text { stories }\end{array}$ & $\begin{array}{l}\text { Grammatical } \\
\text { progression, } \\
\text { non-authentic, } \\
\text { schematic } \\
\text { dialogues as } \\
\text { models for the } \\
\text { everyday } \\
\text { speech }\end{array}$ & $\begin{array}{l}\text { Mostly authentic } \\
\text { originals, other } \\
\text { texts, everyday } \\
\text { texts, usable } \\
\text { texts literal-not } \\
\text { only classical }\end{array}$ & $\begin{array}{l}\text { Addressing the } \\
\text { actual language }\end{array}$ \\
\hline
\end{tabular}




\begin{tabular}{|c|c|c|c|c|c|}
\hline Grammar & $\begin{array}{l}\text { Stand priority } \\
\text { grammar } \\
\text { lessons: } \\
\text { synthetic- } \\
\text { deductive }\end{array}$ & $\begin{array}{l}\text { Very reduced, } \\
\text { grammar } \\
\text { rules } \\
\text { intuitively } \\
\text { lost, example } \\
\text { grammar } \\
\text { (application } \\
\text { of example } \\
\text { text) }\end{array}$ & $\begin{array}{l}\text { There is no } \\
\text { explicit } \\
\text { grammar } \\
\text { teaching, } \\
\text { grammar } \\
\text { through } \\
\text { imitation, there } \\
\text { is no } \\
\text { systematisation } \\
\text { (example text - } \\
\text { exercises- } \\
\text { usage) }\end{array}$ & $\begin{array}{l}\text { Inductive } \\
\text { grammar - } \\
\text { mediation - self- } \\
\text { discovery of rules } \\
\text { (SDR) (example } \\
\text { text -analysis) }\end{array}$ & $\begin{array}{l}\text { Spontaneous } \\
\text { grammar } \\
\text { Contrastive } \\
\text { Grammar }\end{array}$ \\
\hline $\begin{array}{l}\text { Exercises } \\
\text { typical } \\
\text { textbook }\end{array}$ & $\begin{array}{l}\text { Text with gaps, } \\
\text { dictation, } \\
\text { composition, } \\
\text { translation in } \\
\text { both directions } \\
\text { Schulz- } \\
\text { Griesbach } \\
\text { (Szanyi Verm. } \\
\text { methode) }\end{array}$ & $\begin{array}{l}\text { The spoken } \\
\text { language } \\
\text { stands in the } \\
\text { center, } \\
\text { listening } \\
\text { repetition, } \\
\text { free play, } \\
\text { discussions }\end{array}$ & $\begin{array}{l}\text { Pattern Drill } \\
\text { building } \\
\text { sentences, text } \\
\text { with filling, } \\
\text { learning by } \\
\text { heart and } \\
\text { repetition of } \\
\text { dialogs Deutsch } \\
2000\end{array}$ & $\begin{array}{l}\text { Communicative } \\
\text { situations } \\
\text { prepared, } \\
\text { constructed, } \\
\text { structured } \\
\text { exercises, } \\
\text { conversation, } \\
\text { discussion, } \\
\text { Themen, Interk. } \\
\text { Sprachbrucke, } \\
\text { Sichtwechsel }\end{array}$ & $\begin{array}{l}\text { Ordination } \\
\text { exercises, filling } \\
\text { texts, } \\
\text { understandable } \\
\text { texts, etc. Deutsch } \\
\text { ist easy }\end{array}$ \\
\hline
\end{tabular}

ement

language are presented, the different roles they occupy for the inter-language leaming, because sometimes profit is made from the previously studied, sometimes of the language learned later, sometimes from the inter-lingual transfer, sometimes from the transfer-base of the native tongue and the first foreign language (Meibner, 2000, p. 1).

According to Meibner (2004, p. 152), the key terms for the concept of multilingualism are:

Economising the study of foreign languages through systematic networking of the languages, knowledge, pro and retroactive transfer between the native tongue and L1, L2, and L3 or further foreign languages

Differentiation of th

transfer in the language systems from L1, L2, and L3, inter-linguistic transfer)

Focusing on the multilingual language of the student, temporary description of the multilingual systematic (negative/positive rules of correspondence)

experience with different languages and ways of obtaining the language, orientation of the student

Usage of the targeted languages as languages of the surrounding conferred virtually through new technologies. Meibner (2004, p. 152)

Multilingual education can be successful only if the language teaching is restructured and oriented according to the standards of multilingualism (Jessner, 2008, p. 15).

-linguistic intertwining of the strategies for learning, vocabulary and grammar, whilst constructing the teaching materials as well as in planning the curriculum and its implementation. On the one hand, it implies that a linguistic foreknowledge should be adapted in such a manner that enables positive transfer; and on the other hand, to enable the students to be prophylactically kept abreast of possible errors due to 
1.3. Model suggests which can be implemented in a classroom with multilingual students who learn German as a fourth language (L4)

Taking into account the most prominent models of multilingual language learning such as RolleFunctions-Modell/Language switches model, whose representatives are Sarah Williams/Bjom Hammarberg (1998) and the psycholinguistic model of cross-linguistic influences in learning additional languages; Foreign language acquisition model of Maria Groseva (2000) Contrastive-linguistic model: L2 as a reference for building the hypothesis of leaming of L3. Dynamic model of multilingualism of Philip Herdina/Ulrike Jessner (2002), system-theoretic model (Hufeisen, 2004, p. 10). Language changes in individuals, including loss of speech and the commitment to preserve the language. Ecological model of multilingualism Larissa Aronin/Muiris OnLaoire (2004) socio-linguistic model: Attitude to two- and multilingual societies. Didactical multilingual monitor or multilingual machining 
After the first meeting with the target language, the spontaneous grammar for that language is being developed.

In the second phase of meeting the target language, an inter-lingual correspondence with the grammatical rules that will act as a bridge between the earlier language skills and knowledge acquired from the target language is being developed, and the grammatical system will be functional.

In the third phase, the multilingual learning system will be built. This means that students will keep and support (successfully or unsuccessfully) all the inter-lingual transfer processes.

In the fourth phase, teaching experiences of multilingual students are kept as a collection of metacognitive strategy (Jessner, 2008, p. 25).

system is introduced.

er lingual

\section{Method}

Within the empirical part of this thesis whether the didactics of multilingualism can be implemented in Macedonia among Albanian speaking students of the German language, should be investigated, by paying attention to the language situation in Macedonia and of the matching multilingual didactic model.

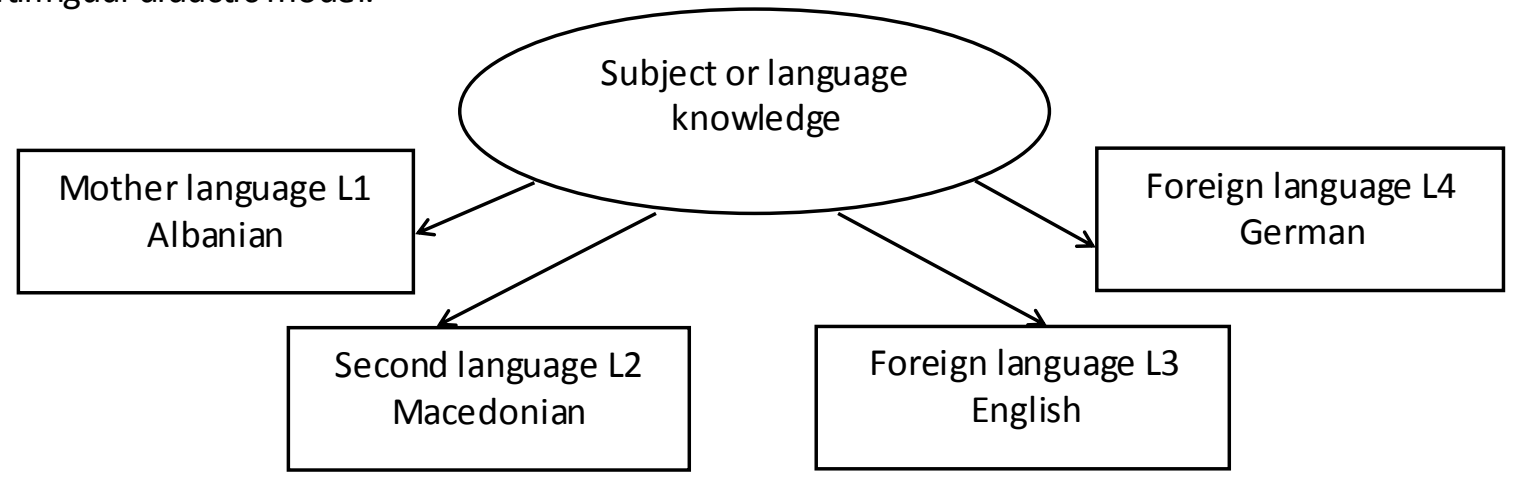

Figure 1. Presentation of the languages studied in Macedonia

Question is:

How can the exercises from a multilingual textbook be made didactic?

Through reformulating the exercises from the schoolbooks of German as a foreign language, wherein the potential vocabulary of all the three languages including the native tongue is considered.

\subsection{Reformulated exercise}

The reformulated exercise can be found in the scho

the following is explored:

there are 22 words that are being used multiple times, and altogether there are 45 words (for 
The number of new words in the text, which are not mentioned in the previous lessons:

Aufenthaltsgenehmigung, Auslander, das Auslanderamt, muss, Einwohnermeldeamt, melden, Visum, Passfotos, Mietvertrag, kompliziert, spezielle, Regeln.

Potential words are:

Monaten, Visum, Passfotos, spezielle, Regeln, spezielle, kompliziert

Unknown words are:

Einwohnermeldeamt, Aufenthaltsgenehmigung, Auslanderamt, Mietvertrag, Auslander

The premises, respectively the given words to identified the new ones are 5:

Leute aus andere Lander, eine Genehmigung fur Aufenthalt in Deutschland, Amt fur Auslander, Meldeamt fur die Einwohner, einen Vertrag fur die Miete.

The exercise was used in teaching as an additional exercise. 15 min were planned for this exercise and the following steps were taken:

\section{Strategy 1:}

Mobilising previous knowledge in order to activate the general knowledge and knowledge of the other languages as well as their native language, everything in the text (images, notes, side notes, images etc), the following activities were undertaken:

A short conversation is conducted with the students about the images, the terms of service for foreigners and the authentic form note for registration (prepared questions, copies/group work). At

\section{Strategy 2:}

Building hypothesis reflection of the text content and issues, starting from some familiar information was achieved. Students read the text once and during reading they should highlight the potential words. And through them they should think about the possible meaning of the new words.

\section{Strategy 3:}

In order to develop sense for the most important elements in the text, at this stage, they rewrite the unknown words and internationalisms in their notebooks and leave them without translation, and then they close their books.

\section{Strategy 4:}

To understand the text that they are to read with closed books, a text with gaps is given to them and according to their hypothesis they check the meaning of the word several times, and then they fill the gaps with the aid of the given premises. The main aim is to awaken the students, with what other words it could be connected in order to understand the unknown word.

\section{Results}

The result of the analysis is in Table 1, which support Reinfr of multilingualism coincides with the principle of leaming with interdisciplinary teaching, whileTable 2 indicates that the didactics of multilingualism as a concept is built based on the idea of a comprehensive curriculum for languages in which different languages communicate with each other, stand in close interaction.

Considering the construction of the in-class activities and exercises based on multilingual didactics, the results indicate that out of 35 participants 27 of them filled the gaps, 8 of them partially, and for 
the native tongue stands first in the heads of the students, in case no other solution is fo und.

After the discussion with the students, a conclusion has been made that the premises were additional help only for the good learners, others were confused because they had an additional task, i.e., they had to think of the meaning of the word which caused additional difficulties. However,

answer when reading the assignment.

\section{References}

Hufeisen, B. (2004). Das haben wir doch immer schon gemacht! Oder ein Paradigmenwechsel in der Spracherwerbsforschung? In K. R. Bausch, F. G. Konigs \& H. J. Krumm (Eds.), Mehrsprachigkeit im Fokus. GiessenerBeitragezurFremdsprachendidaktik. Tubingen, Germany: Gunter Narr Verlag.

Hufeisen, B. \& Gibson, M. (2003). Zur Interdependenz emotionaler und kognitiver Faktoren im Rahmen eines Modells zur Beschreibung sukzessiven multiplen Sprachenlernens. Bulletin VALS-ASLA (Vereinigung furangewandte linguistik in der Sch weiz), 78, 1333.

Jessner, U. (2008), Teaching third languages: Findings, trands and challenges. Language Teaching, 41(1), 1556.

Meibner, F. J. (2004). Transfer und Transferieren. Anleitungen zum Interkomprehensionsunterricht. Germany: Klein \& Rutke.

Reinfried, M. (1998). Transfer beim Erwerb einer weiter en romanischen Fremdsprache. Prinzipielle Relevanz und methodische Integration in den Fremdsprachenunterricht. In F. J. Meibner, M. Reinfried (Hrsg.), Mehrsprachigkeitsdidaktik, Konzepte, Analysen, Lehrererfahrungenmit romanischen Fremdsprachen. Tubingen, Germany: Gunter Narr Verlag.

Reinfried, M. (2001). Neokommunikativer Fremdsprachenunterricht: ein neues methodisches Paradigma. In F. J. Meibner, M. Reinfried (Hrsg.), Bausteine fur ein en neokommunikativen Franzosischunterricht. Tubingen, Germany: Gunter Narr Verlag.

Van der Geer, J., Hanraads, J. A. J. \& Lupton, R. A. (2000). The art of writing a scientific article. Journal of Science Communication, 163, 5159. 


\section{Appendix}

Reformulated exercise from 'studio d $1 A^{\prime}$ ' page 85, exercise 6

Damit man in Deutschland wohnt, muss man sich beim Einwohnermeldeamt und Auslanderamt anmelden.

(Leute aus andere Lander) brauchen in Deutschland nach drei Monaten eine (eine Genehmigung fur Aufenthalt in Deutschland). Die

Aufenthaltsgenehmigung hat man immer fur ein Jahr. Das (Amt fur Auslander) fragt nach dem Visum, nach drei Passfotos und nach der Wohnung. Die Wohnung muss man beim (Meldeamt fur die Einwohner) melden.Fur die Wohnung hat man einen Landern spezielle Regeln. (einen Vertrag fur die Miete). Kompliziert? Ja, aber fur Auslander gibt es in allen drei Monaten eine (Leute aus andere Lander) brauchen in Deutschland nach Aufenthaltsgenehmigung hat man immer fur ein Jahr. Das (n) fragt nach dem Visum, nach drei Passfotos und nach der Wohnung. Die Wohnung muss man beim (Meldeamt fur die Einwohner) melden.Fur die Wohnung hat man einen Landern spezielle Regeln. (einen Vertrag fur die Miete). Kompliziert? Ja, aber fur Auslander gibt es in allen 